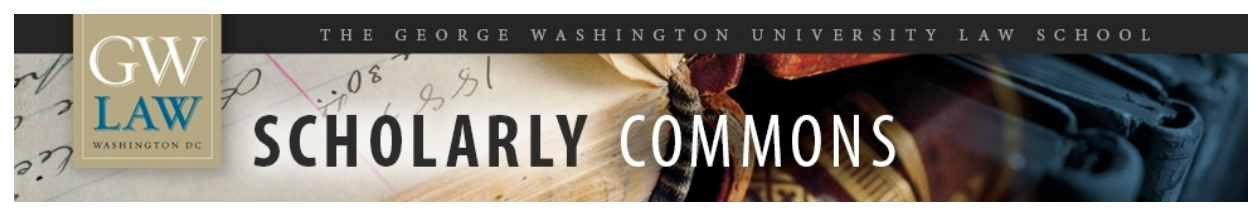

\title{
Effects of the COVID-19 Pandemic on the Work of the International Law Commission
}

\section{Sean D. Murphy}

George Washington University Law School, smurphy@law.gwu.edu

Follow this and additional works at: https://scholarship.law.gwu.edu/faculty_publications

Part of the Law Commons

\section{Recommended Citation}

Murphy, Sean D., Effects of the COVID-19 Pandemic on the Work of the International Law Commission, American Journal of International Law, vol. 114 (forthcoming 2020).

This Article is brought to you for free and open access by the Faculty Scholarship at Scholarly Commons. It has been accepted for inclusion in GW Law Faculty Publications \& Other Works by an authorized administrator of Scholarly Commons. For more information, please contact spagel@law.gwu.edu. 


\title{
CURRENT DEVELOPMENTS
}

\section{EFFECTS OF THE COVID-19 PANDEMIC ON THE WORK OF THE INTERNATIONAL LAW COMMISSION}

\author{
By Sean D. Murphy*
}

The International Law Commission (ILC) was scheduled to hold its seventy-second session from April 27 to June 5 and from July 6 to August 7, 2020 in Geneva. ${ }^{1}$ The COVID-19 pandemic, however, precluded the Commission members traveling to and meeting in Geneva. As such, it became necessary to postpone the session until 2021 and to address various collateral matters, including whether the current five-year terms of Commission members should be extended by one year, so as to conclude in 2022 instead.

By mid-March 2020, it became evident that the pandemic would preclude the Commission from meeting in Geneva during the first half of its planned session. Since the regional groups of the Commission informally had agreed upon which five members of those groups would serve on the Commission's bureau for the upcoming seventy-second session, that "incoming bureau" coordinated with the "outgoing bureau" of the seventy-first session (which continues to serve until the seventy-second session) on a recommendation from the Commission to the General Assembly. Based on Commission's recommendation, the Assembly decided in April 2020 to postpone the first half of the Commission's session and to add a further week to the second half. ${ }^{2}$ (Given the difficulty for the Assembly itself to meet in New York, a "silence procedure" procedure was used whereby a draft decision was circulated to member states and, in the absence of objection after a short period of time, the decision was deemed adopted. ${ }^{3}$ )

By the end of May, however, it became clear that the pandemic would preclude any meeting of the Commission during the summer of 2020. Consequently, the Commission recommended that the seventy-second session be postponed in its entirety to 2021 and that the terms of office of the current members, which normally would end in 2021 , be extended so as to conclude in 2022. The Commission's recommendation, however, encountered concerns by some member states, principally related to the precedent that such an extension might have for other U.N. bodies and to a desire that the Commission explore making progress in a virtual format. After initial informal consultations, in June 2020 the General Assembly only decided that the seventysecond session would be postponed to a later date. ${ }^{4}$

* Manatt/Ahn Professor of International Law, George Washington University, and member of the UN International Law Commission.

${ }^{1}$ G.A. Res. 74/186, para. 16 (Dec. 18, 2020).

${ }^{2}$ G.A. Dec. 74/545 (Apr. 2, 2020). The draft decision appears at U.N. Doc. A/74/L.45 (Mar. 27, 2020) and its adoption is reflected in a letter of the President of the General Assembly of April 2, 2020, https://www.un.org/pga/74/2020/04/02/seventy-second-session-of-the-international-law-commission-2/.

${ }^{3}$ G.A. Dec. 74/544 (Mar. 27, 2020).

${ }^{4}$ G.A. Dec. 74/559 (June 23, 2020). The draft decision appears at U.N. Doc. A/74/L.70 and its adoption is reflected in a letter of the President of the General Assembly of June 23, 2020, https://www.un.org/pga/74/2020/06/23/postponement-of-the-seventy-second-session-of-the-international-lawcommission-2/. 
After more extensive informal consultations, the General Assembly in August 2020 decided that the seventy-second session would be held in Geneva in 2021 and that the seventy-third session would be held in 2022. ${ }^{5}$ Further, the Assembly decided that Commission members' terms of office "shall be extended by one year such that they will expire on 31 December 2022, in order to permit the current membership to complete consideration of the topics on the programme of work for the seventy-second and seventy-third sessions that are at an advanced stage." 6 The Assembly stressed that this decision to extend was taken "on an exceptional basis, owing to the unprecedented circumstances arising" from the pandemic, and "does not constitute a precedent, either for the Commission or for other bodies of the United Nations with elected members."7

In light of this decision, the Commission's work that was anticipated for 2020 should now occur in 2021, while the work for 2021 should occur in 2022. As such, in 2021 the Commission is expected to complete (on second reading) its work on two topics: (1) protection of the atmosphere; ${ }^{8}$ and (2) provisional application of treaties. ${ }^{9}$ In 2022, the Commission should complete (on second reading) its work on two further topics: (1) peremptory norms of general international law (jus cogens); ${ }^{10}$ and (2) protection of the environment in relation to armed conflicts. ${ }^{11}$ Further, it is hoped that the first reading of the draft articles on the immunity of state officials from foreign criminal jurisdiction will also be completed in 2022. ${ }^{12}$ Work will continue on other topics on the Commission's current work program: succession of states in respect of state responsibility; ${ }^{13}$ general principles of law; ${ }^{14}$ and sea-level rise in relation to international law. ${ }^{15}$

The General Assembly's August decision also urged the Commission to explore means for making progress on its topics during 2020 in the absence of in-person meetings ${ }^{16}$ and requested the Commission's secretariat to prepare options to enable the Commission to effectively conduct its work remotely, including in the event that it is unable to hold in-person sessions beyond $2020{ }^{17}$ Aside from the normal challenges of virtual meetings (such as access to reliable internet connectivity), a central difficulty that the Commission faces in conducting work virtually is that it operates in the six official languages of the United Nations. Thus, whenever a member speaks at a Commission session, it is translated simultaneously into five other languages, a step that may be technically possible through video-conferencing, but nevertheless presents new logistical and cost

${ }^{5}$ G.A. Dec. 74/566, para. (a) (Aug. 12, 2020). The draft decision appears at U.N. Doc. A/74/L.78 (Aug. 6 , 2020) and its adoption is reflected in a letter of the General Assembly President of August 12, 2020,

https://www.un.org/pga/74/2020/08/13/extension-of-the-term-of-office-of-the-current-members-of-the-internationallaw-commission-and-other-related-matters- $2 /$.

${ }^{6}$ G.A. Dec. 74/566, para. (e).

${ }^{7}$ Id., para. (f).

${ }^{8}$ For discussion of prior work on this topic, see Sean D. Murphy, Anniversary Commemoration and Work of the International Law Commission's Seventieth Session, 113 AJIL 90, 96-97 (2019).

${ }^{9}$ For discussion, see id. at 97-10; Sean D. Murphy, Peremptory Norms of General International Law (Jus Cogens) and Other Topics: The Seventy-First Session of the International Law Commission, 114 AJIL 68, 85 (2020).

${ }^{10}$ For discussion, see $i d$. at $68-72$.

${ }^{11}$ For discussion, see $i d$. at 72-75.

${ }^{12}$ For discussion, see $i d$. at 81-82.

${ }^{13}$ For discussion, see $i d$. at $78-81$.

${ }^{14}$ For discussion, see $i d$. at 82-84.

${ }^{15}$ For discussion, see $i d$. at 84-85.

${ }^{16}$ G.A. Dec. 74/566, para. (b).

${ }^{17}$ Id., para. (c). 
issues. Further, the Commission members are scattered across global time zones (as are U.N. translators), making it infeasible to schedule a full day of meetings. Much of the work of the Commission is comparable to the negotiation of a multilateral treaty, in which there are numerous informal draft texts in various languages and seriatim interventions by members (especially in the drafting committees) that require "reading the room" and understanding subtleties in positions, which can be lost in a virtual environment. Likewise, resolution of differences on the margins of the formal meetings becomes more difficult. Nevertheless, in light of the inability to engage in its work during the summer of 2020, it appears that the Commission and its secretariat will now explore new ways to conduct the Commission's work, as are international organizations and, indeed, the world generally.

A remaining issue is the timing of the election for the next Commission. Previously, the U.N. secretary-general would have scheduled the election for late 2021 , in the expectation that the elected members would assume office in January 2022. Some countries had already announced their candidates and begun campaigning with that expectation in mind. ${ }^{18}$ Yet with the terms of the members of the next Commission commencing in 2023, the secretary-general might decide to hold the election in late 2022 instead.

${ }^{18}$ See, e.g., Japan Ministry of Foreign Affairs Press Release, The Nomination of Professor ASADA Masahiko, Kyoto University, as a Candidate for Election to the International Law Commission (ILC) in 2021 (Jan. 10, 2020), https://www.mofa.go.jp/press/release/press4e_002751.html\#: :text=The\%20Government\%20of\%20Japan\%20has,U nited\%20Nations\%20in\%20autumn\%202021. 